\title{
Grain, meat and vegetables to feed Paris: where did and do they come from? Localising Paris food supply areas from the eighteenth to the twenty-first century
}

\author{
G. Billen $\cdot$ S. Barles $\cdot$ P. Chatzimpiros • \\ J. Garnier
}

Received: 12 March 2011/Accepted: 24 June 2011/Published online: 7 July 2011

(C) The Author(s) 2011. This article is published with open access at Springerlink.com

\begin{abstract}
The food supply to a large metropolis such as Paris involves huge fluxes of goods, which considerably impact the surrounding rural territories. Here, we present an attempt to localise Paris food supply areas, over a period of two centuries $(1786,1886,2006)$, based on the analysis of data from transportation and production statistics for cereals, animal products, and fruits and vegetables, all three categories being expressed in terms of their nitrogen (i.e. protein) content. The results show contrasting trends for the three types of agricultural products. As for cereals, the Paris supply area remained for the most part restricted to the central area of the Paris basin, a region which gradually became specialised in intensive cereal production. Conversely, as animal farming had been progressively excluded from this area, regions located west and north of Paris (Brittany, Normandy, Nord-Pas-de-Calais) gradually dominated the supply of animal products to the metropolis. In addition, imported feed from South America today contributes as much as one-third of the total ration of feed in the livestock raised in these regions. For fruits and vegetables, about one-half of the Paris supply currently comes from long-distance imports, the other half coming from areas less than $200 \mathrm{~km}$ from Paris. As a whole, the Paris food supply area, although it has obviously enlarged in recent periods, is still anchored to an unexpected extent (about 50\%) in its traditional nearby hinterland roughly coinciding with the Seine watershed, and in the regions specialised in animal farming located west and north. On
\end{abstract}

G. Billen $(\bowtie) \cdot$ J. Garnier

UPMC-CNRS, UMR Sisyphe, Paris, France

e-mail: Gilles.Billen@upmc.fr

S. Barles · P. Chatzimpiros

LATTS, Marne-la-Vallée, France the other hand, the agricultural system of the main food supply areas has considerably opened to global markets.

Keywords Urban footprint - Nitrogen ·

Paris metropolitan area $\cdot$ Food $\cdot$ Supply areas $\cdot$ Hinterland

\section{Introduction}

Meeting the food demand of a large city is obviously one of the primary concerns of urban management and is also a major driver of the influence a city exerts on surrounding rural territories, by perturbing the cycle of major nutrients, including carbon, nitrogen and phosphorus. The food supply of some cities is ensured by very distant areas, as was the case of Rome in Antiquity (Morley 1996), but also of London in more recent times (Peet 1969). In this respect, Paris offers the example of a city that depended longer on a rather close hinterland for its food supply (Billen et al. 2009), mostly located within the geologically defined sedimentary Paris basin. The Paris metropolitan area has increased its population by a factor of 20 since the end of the eighteenth century. The resulting growth in food demand must therefore have exerted a considerable influence on the surrounding supply areas. We have already shown that the demographical development of the city was paralleled by profound mutations in the agricultural sector of the Paris basin, which first made it able to follow the urban food demand and then, more recently, to increase its potential for commercial export far beyond the needs of the local urban market (Billen et al. 2009). We did not assess, however, the effective location of the areas participating in the Paris food supply over this long period. The present work is an attempt to do so for three time points one century apart $(1786,1896,2006)$ selected for data 
availability. The results of this assessment provide insight into the long-term changes in the relationships between a large city and its rural hinterland in the context of rapid development of transport infrastructures and economic globalisation.

\section{Methods}

Defining the Paris agglomeration

The precise definition of an urban agglomeration is somewhat arbitrary, because it necessarily mixes operational considerations related to the existence of statistical data collected according to administrative units with conceptual considerations on the distinction between urban and rural territories. At the end of the eighteenth century, most of the urban population lived intra muros so it is easier to give an estimate than in present times. Official censuses only began in 1801, providing a figure of 550,000 for Paris (3,370 ha) and less than 50,000 for the rest of the Seine département in which Paris was enclosed. The population before the French Revolution (1789) might have been slightly higher; Fierro (1996) gives the figure of 600,000 inhabitants for Paris in 1780, and Favier (1997) suggests the figure of 700,000 inhabitants for Greater Paris, including Versailles. We chose the last figure for this study, as it is more in line with what we would presently define as the urban agglomeration.

One century later, the Paris agglomeration was quite different. Paris itself covered a wider area (7,800 ha) and had 2,536,834 inhabitants. Its suburbs had developed tremendously. Dupeux (1981) has calculated the past evolution of Paris and its suburbs. According to his assumptions, a municipality belongs to the Paris metropolitan area when it has at least 3,000 inhabitants and is contiguous to Paris or to another contiguous municipality. Using this definition, the population of the metropolitan area reached 2,984,097 inhabitants in 1891 and 3,500,617 in 1901, very close to the population of the Seine département. Most municipalities that were included in the metropolitan area according to Dupeux were indeed within the Seine département. We therefore matched the population of Paris and its suburbs in 1896 to that of the Seine département $(3,340,514$ inhabitants).

Today, the official limits of the Paris metropolitan area as established by INSEE (2007) are based on a building continuity criterion and include all towns of more than 2000 inhabitants with at least half their population living in the urbanised area. So defined, present (2006) metropolitan Paris totals 10,197,678 inhabitants (INSEE 2007). This accounts for $88 \%$ of the total population of the Île-de-France region, comprising the four administrative départements previously forming the Seine département and the more rural départements of Val-d'Oise, Yvelines, Essonne and Seine-et-Marne. As most of the data used in this paper concern départements and the region, we assume that, in 2006, the population of the metropolitan area equalled the population of the Île-de-France region $(11,532,000$ inhabitants in 2006).

The Parisian diet

Calculating Paris's food requirements requires knowledge of the per capita diet and its modifications over the two centuries covered by this study. Several studies have investigated this subject (Barles 2007; Billen et al. 2007, 2009) and are summarised in Table 1 . To compare their nutritional value, we express all food items in terms of their nitrogen (i.e. protein) content. Other choices could have been made, e.g. by expressing all figures in terms of calories, but we preferred nitrogen both because of the central role of proteins in human nutrition and because of this study's interest in the nitrogen issue (Sutton et al. 2011). The conversion factors used $(1.8 \% \mathrm{~N}$ for cereals, $3.4 \% \mathrm{~N}$ for meat, $0.5 \%$ for milk and $0.1-0.4 \%$ for most fruits and vegetables) were presented in Billen et al. (2009). We recognise that grouping all food items into three categories (grain, animal products and fruits and vegetables) is a simplification that masks a much larger variability of properties, nitrogen content, economical values and origins. This was required, however, to provide an overall view of the Paris food supply.

Over two centuries, these data reveal a major decreasing trend in the share of cereals in the total diet, from 57 to $17 \%$, replaced by animal products, which increased from 39 to $69 \%$, and fruits and vegetables, increasing from 4 to $14 \%$.

Tracing the origin of food imports

The extensive study by Abad (2002) on the Paris food supply at the end of the eighteenth century was used as the

Table 1 Per capita food consumption of Paris inhabitants, in terms of nitrogen content

\begin{tabular}{lccc}
\hline gN/inhab/day & 1786 & 1896 & 2006 \\
\hline Bread and other cereals products & 8.30 & 7.20 & 3.70 \\
Meat & 3.60 & 8.00 & 8.10 \\
Fish & 1.10 & 1.00 & 2.10 \\
Milk, cheese and eggs & 1.07 & 2.00 & 5.10 \\
Fruit and vegetables & 0.58 & 1.10 & 3.10 \\
Total (gN/inhab/day) & 14.6 & 19.3 & 22.1 \\
\hline
\end{tabular}


baseline in the present study. In addition to the data from the city toll statistics (which do not include information on their source), Abad provides a detailed account of the province of origin of most food items consumed in Paris, based on a careful historical enquiry.

For 1896, we used the Rapport annuel de l'année 1896 sur les services municipaux de l'approvisionnement de Paris edited by the Supply Department of the Seine département (Bureau de l'Approvisionnement 1897) providing the amounts of grain delivered to Paris by waterways, road and the six main railway companies, namely the State Company and the Compagnies du Nord, de l'Est, de l'Ouest, d'Orléans, and Paris-Lyon-Méditerranée. Knowing the départements served by each of these companies (Jouanne 1859), the amount originating from each département was calculated pro rata with their respective potential for export, as determined from agricultural statistics (Ministère du Commerce et de l'Industrie 1897). For meat, the Statistique agricole annuelle (1897) was used: this yearly publication mentioned the origin of the animals imported into Paris (providing beef, mutton and pork).

For 2006, the SitraM database (Système d'Information sur les Transports de Marchandises) established by the French Ministry of Transport (MEDDEM, www. statistiques.equipement.gouv.fr/) was used, providing a detailed matrix of transportation fluxes (by road, rail, air and water) between all French départements and foreign countries, according to a commodity code distinguishing 176 items, including more than 50 agricultural goods. Let us call this matrix $\{\boldsymbol{I}(\boldsymbol{d}, \boldsymbol{o})\}$ for a given commodity and a given year, with $\mathrm{d}$ referring to destination and o to origin. Internal transport fluxes $\boldsymbol{I}(\boldsymbol{i}, \boldsymbol{i})$ are not considered but are replaced by the domestic production of the commodity, extracted from national agricultural statistics (Agreste 2006). Let this modified matrix be called $\{\boldsymbol{I}(\boldsymbol{d}, \boldsymbol{o})\}$. We assume that the distribution by origin of internal consumption is the same as that of imports plus internal production, even if a significant proportion of imports is re-exported. This 'perfect mixing' assumption is obviously a rough but unavoidable idealisation, which implies that any 'local preference' in consumption is ignored. Using a first-order procedure, the distribution of origins can be calculated as:

$$
\begin{gathered}
\left\{\boldsymbol{r}_{1}(\boldsymbol{a}, \boldsymbol{i})\right\}=\left\{\boldsymbol{I}^{*}(\boldsymbol{a}, \boldsymbol{i}) / \sum_{j=\text { all } o}\left(\boldsymbol{I}^{*}(\boldsymbol{a}, \boldsymbol{j})\right)\right\} \\
\text { with } 0 \leq r_{1} \leq 1 \text { and } \sum_{i} \boldsymbol{r}_{1}(\boldsymbol{a}, \boldsymbol{i})=1 .
\end{gathered}
$$

In a second-order step, because the SitraM database refers to origin defined as the place of last loading, possible previous origins of the commodity should be taken into account (Fig. 1). For the secondary origins for foreign countries, not covered in the SitraM database, FAO trade statistics were used. Here again, perfect mixing is assumed, and the flux from any origin is given by the contribution of this origin to the total imported fluxes (Fig. 1):

$\left\{\boldsymbol{r}_{2}(\boldsymbol{a}, \boldsymbol{i})\right\}=\left\{\left[\sum_{k=\text { allo }}\left(\boldsymbol{I}^{*}(\boldsymbol{a}, \boldsymbol{k}) \cdot \boldsymbol{r}_{1}(\boldsymbol{k}, \boldsymbol{i})\right)\right] / \sum_{j=\text { allo }}\left(\boldsymbol{I}^{*}(\boldsymbol{a}, \boldsymbol{j})\right)\right\}$.

In practice, we used the second-order procedure only for those origins contributing more than $5 \%$ to the first order.

\section{Results}

The Paris food supply areas in 1786

At the end of the eighteenth century, Paris was already a huge city of about 700,000 inhabitants. Surprisingly, the results reported by Abad (2002), when converted in terms of $N$ content, indicate that, in spite of a food market extending over the entire Kingdom of France and beyond, Paris kept most of its 'foodprint' within the limits of the Seine watershed, i.e. within a radius of about $150 \mathrm{~km}$ (Billen et al. 2009) (Fig. 2a-c). The grain supply mostly came from the Île-de-France, Champagne and Brie regions, with an estimated weighted distance of $110 \mathrm{~km}$. Meat originated from more distant regions, including the Normandy and MarcheLimousin provinces, where animals were often fattened and walked to the capital. The weighted mean supply distance was approximately $255 \mathrm{~km}$. Fruits and vegetables were for the most part brought from closer regions, with an estimated supply distance of $87 \mathrm{~km}$.

As already discussed by Billen et al. (2009), these results are consistent with the estimated potential for exportation of the agrarian systems of the end of the eighteenth century. With a mean value of $50 \mathrm{kgN} / \mathrm{km}^{2} /$ year for this potential, the above-cited $150 \mathrm{~km}$ radius would be

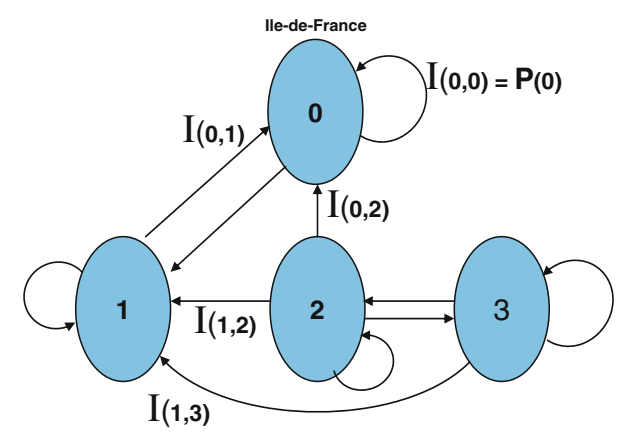

Fig. 1 Diagram showing the logic behind the calculation of the distribution of the origins of commodities from the transport flux matrix between supply areas (French départements and foreign countries) represented here as blue ellipses. In the example, territory 3 , since it does not directly export to territory 0 , is ignored in a firstorder approach, while the contribution of origin 1 and 3 are overestimated. At the second-order approach, the contribution of territory 3 in the fluxes $I(0,1)$ and $I(0,2)$ is considered 
Fig. 2 Contribution of the French provinces to the Paris food supply at the end of the eighteenth century, according to the figures assembled by Abad (2002) a for bread and cereals, b meat and $\mathbf{c}$ fruits and vegetables, all in terms of $N$ content. The distribution of supply distances is also indicated
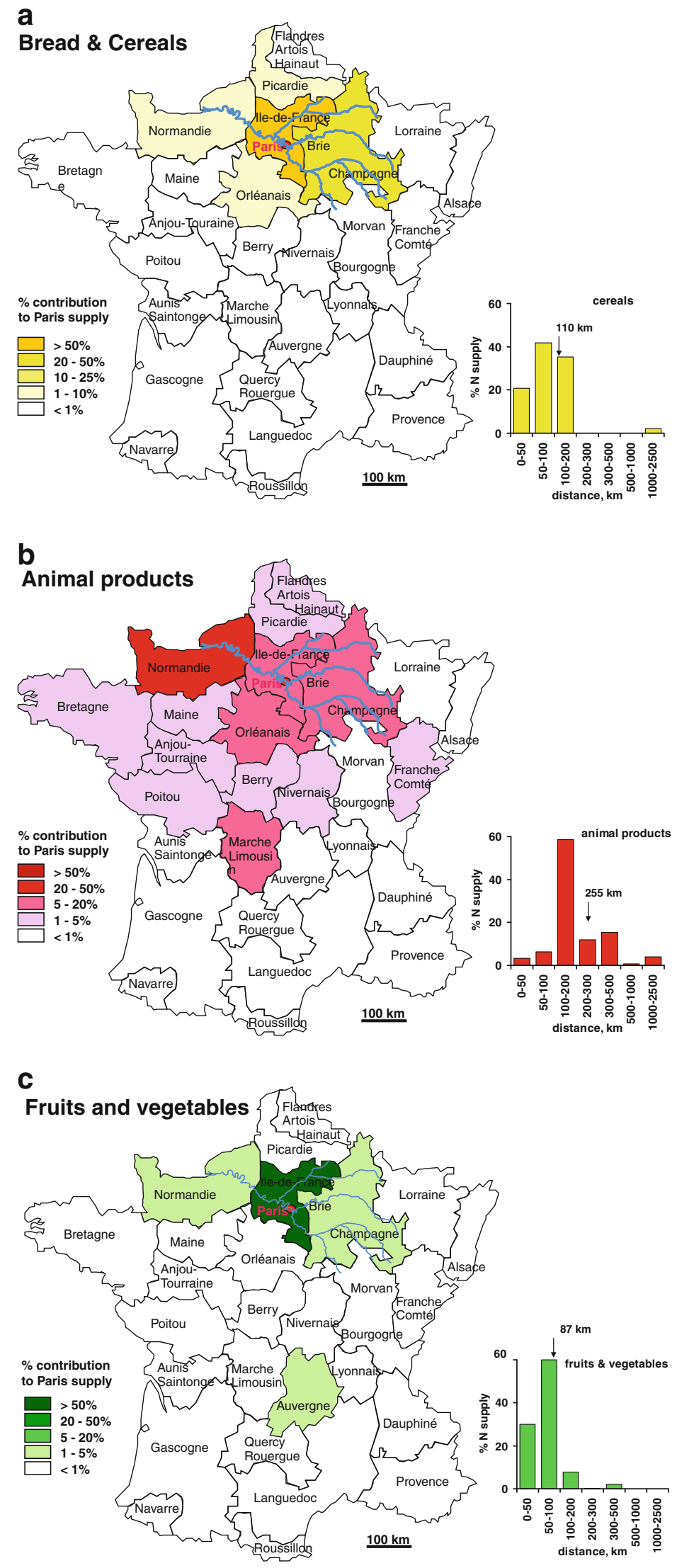
enough to feed a city of 700,000 inhabitants, consuming as a mean $5 \mathrm{kgN} /$ capita/year.

As discussed in earlier reports (Barles 2007; Billen et al. 2009; Kim and Barles 2011), the same territory also provided most of Paris's energy supply, as wood (mainly for heating, cooking and baking) and forage (mainly for feeding horses). Wood was for the most part floated from Morvan forest areas and accounted for about $1.5 \mathrm{kgN} /$ capita/day. Hay came largely from the alluvial Seine valley upstream from Paris and, together with other forage, totalled about $1.7 \mathrm{kgN} /$ capita/year.

The Paris food supply areas in 1896

The nineteenth century was marked by a fivefold increase in the Paris population, which reached 3,340,000 by 1896 . Two other major changes occurred, with opposite potential effects on the city's food supply. First, transport infrastructures developed considerably, making commodity supply from more distant regions possible. The course of the Seine and its main tributaries (the Marne and the Oise) were canalised and regulated for navigation in all seasons; new channels were dug linking the Seine watershed to the Scheldt, the Rhine and the Rhone (Mouchel et al. 1998). Railway development was even more spectacular: begun in the 1840 s, the networking of the entire country was completed by the end of the century, according to a radial scheme centred on Paris (Jouanne 1859). For grain, available transport statistics indicate that railways delivered $86 \%$ of the total supply to the capital, while waterways and roads contributed 12 and $2 \%$, respectively. Cattle transportation by railway also became the norm. On the other hand, agricultural productivity increased considerably, particularly in the Paris basin, owing to the progressive replacement of the triennial fallow with legume fodder crops and the increase in livestock densities, providing more abundant manure resources (Mazoyer and Roudart 1998; Billen et al. 2009). The potential for commercial grain export from rural areas, as calculated on a département basis from agricultural statistics (production of wheat and rye minus estimated consumption by the département's population), is shown in Fig. 3. Values close to or higher than $500 \mathrm{kgN} / \mathrm{km}^{2} /$ year were observed in the regions surrounding Paris. With such agricultural productivity, the $150 \mathrm{~km}$ radius mentioned above would suffice to feed 5,000,000 urban inhabitants with the diet of the time. Grain deficits were logically observed in the départements with a large city (Paris, Lyon, Bordeaux, Marseille, Lille), as well as in Normandy, Brittany and the southernmost départements.

Combining transport statistics (Bureau de l'Approvisionnement 1897) with potential export by département allowed us to calculate the likely distribution of Paris grain supply by supply area (Fig. 4). The result shows that

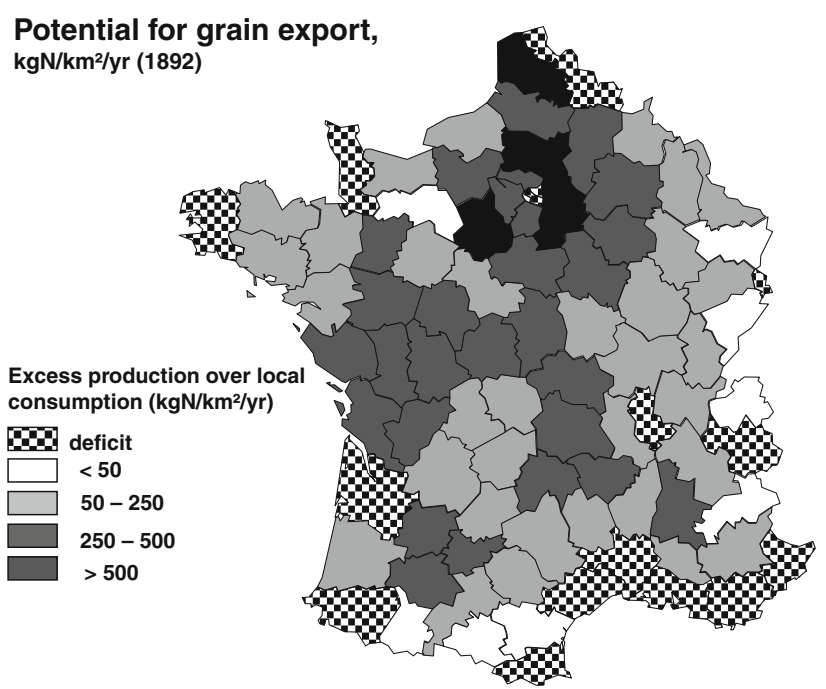

Fig. 3 Potential for grain export (excess wheat and rye production over consumption by local population, expressed in $\mathrm{kgN}$ per $\mathrm{km}^{2}$ territory annually) calculated by départements from 1892 agricultural statistics (Ministère du Commerce et de l'Industrie 1896). The chequered départements are deficit areas

although the supply area had extended since the end of the eighteenth century, the Paris basin still met the bulk of the city's grain demand at the end of the nineteenth century. The weighted mean transportation distance was $177 \mathrm{~km}$. As far as meat and milk products are concerned, the situation was quite similar: only a limited extension of the supply areas occurred compared to the end of the eighteenth century, the supply distance increasing from 255 to $325 \mathrm{~km}$. Regarding fruits and vegetables, the official Rapport sur l'Approvisionnement de Paris (1896) indicates that $82 \%$ of the quantities transported to Les Halles (Paris's central food market) came from the Île-de-France region either by cart or by a regional railway line. The remaining $18 \%$ of the supply came from other French départements, either by train or fluvial transport. The map in Fig. $4 \mathrm{c}$ was drawn by combining agricultural production statistics and transport data. The average supply distance was about $97 \mathrm{~km}$.

The Paris food supply areas in 2006

During the twentieth century, the Paris metropolitan area more than tripled, reaching 11,532,000 inhabitants by 2006. At the same time, agricultural productivity underwent an unprecedented increase owing to the generalisation of synthetic nitrogen fertiliser use. Because manure and atmospheric nitrogen-fixing crops ceased to be the sole sources of cropland fertilisation, livestock farming and crop farming were completely separated, resulting in a strong geographical specialisation: livestock left the central Paris basin, while peripheral regions such as Normandy, 
Fig. 4 Contribution of the French départements to Paris supply of a grain, $\mathbf{b}$ meat and milk products and $\mathbf{c}$ fruits and vegetables at the end of the nineteenth century. The distribution of supply distances is also indicated

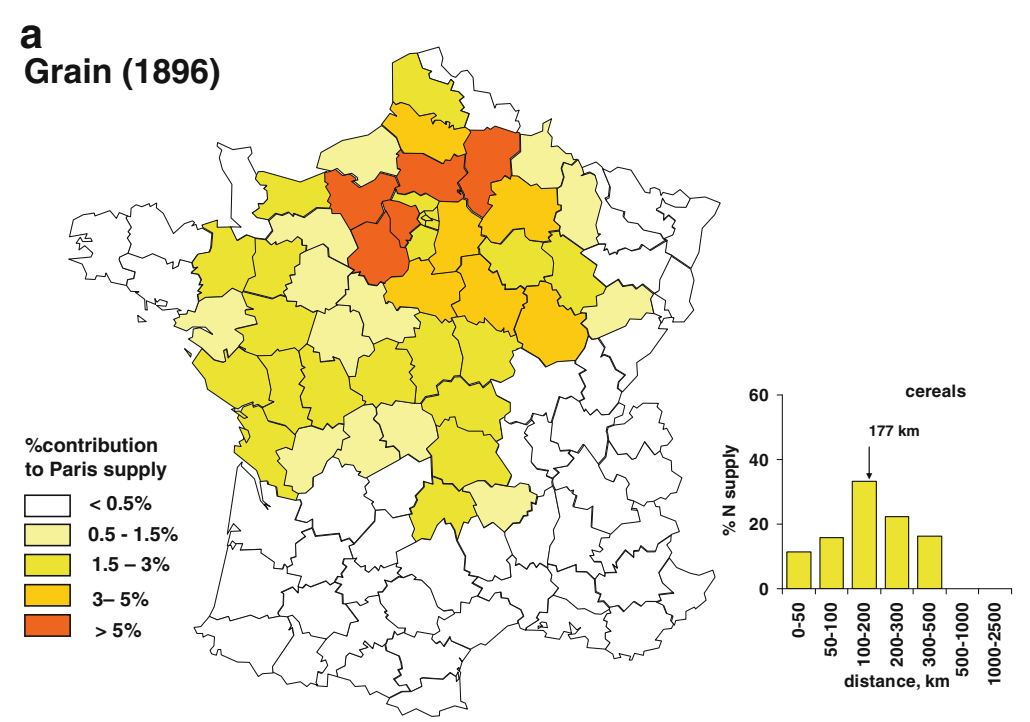

b

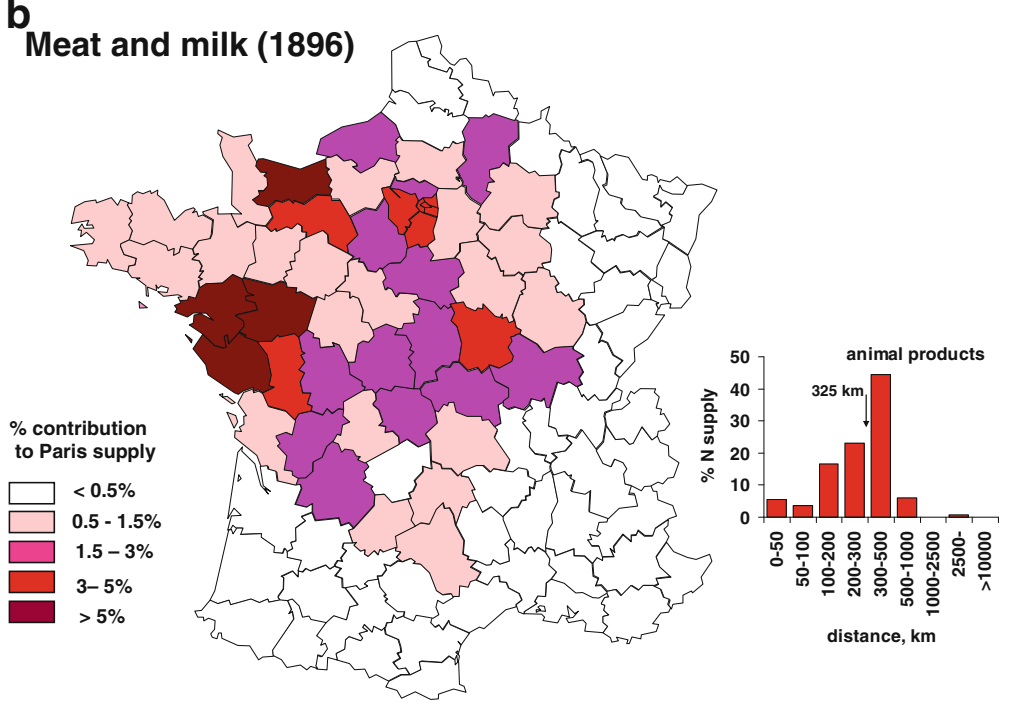

C

Fruits et vegetables (1896)

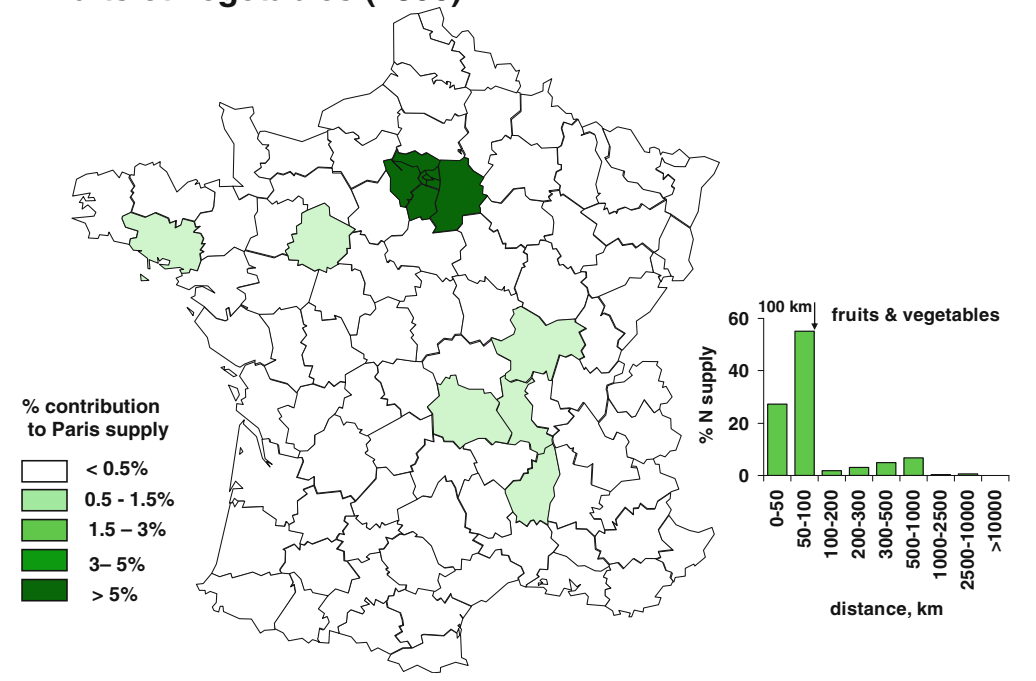



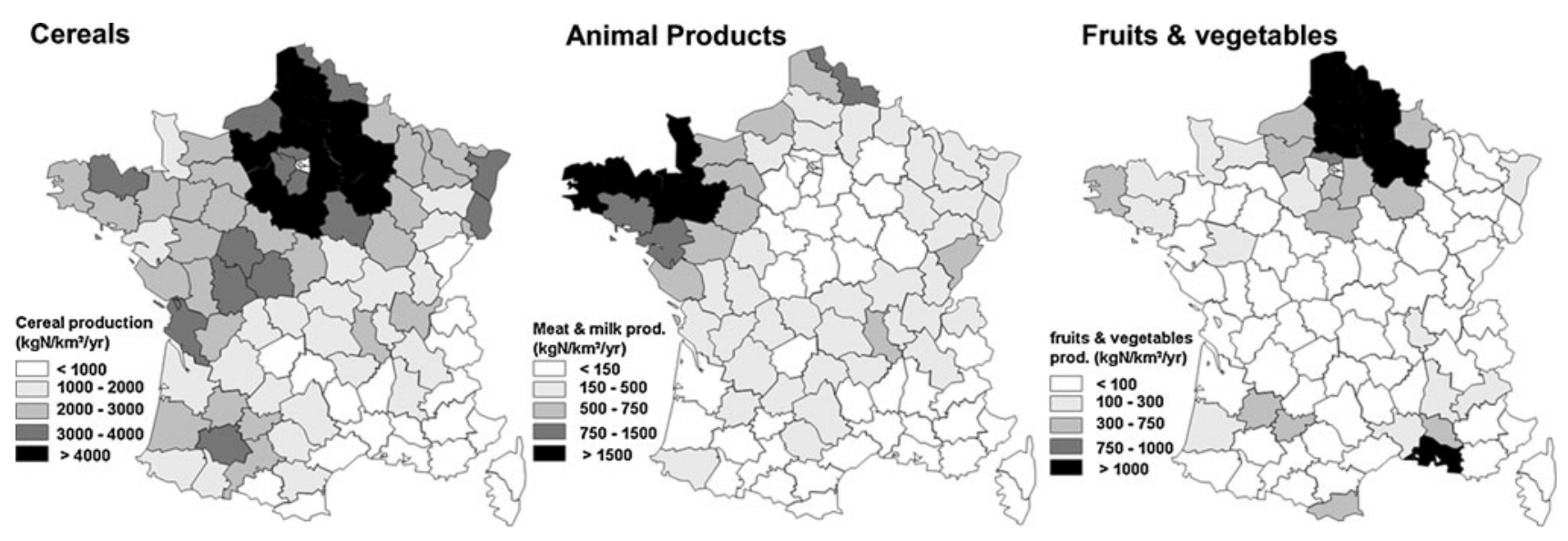

Fig. 5 Territorial productivity (i.e. expressed in $\mathrm{kgN}$ per $\mathrm{km}^{2}$ of total territory annually) of cereals, animal products, and fruits and vegetables in the French départements in 2006. (Agreste 2006)

Brittany to the west and Flanders to the north specialised in animal farming, importing a significant part of their feed. Figure 5 illustrates the results of these changes. Cereal production in the central Paris basin was over $4,000 \mathrm{kgN} /$ $\mathrm{km}^{2} /$ year. Productivity levels over $1,000 \mathrm{kgN} / \mathrm{km}^{2} /$ year were also found for meat and milk or vegetable production in the corresponding specialised areas. Obviously, Paris could not remain the major market absorbing the agricultural production of these regions.

Simultaneously, transport infrastructures also developed tremendously. Road transportation largely supplanted the railway in national transport; the former supplied $75 \%$ of total final food delivery to Paris, whereas the latter provided only $18 \%$, with waterways transporting $7 \%$. Longdistance international marine traffic using container cargos also developed, now connecting Paris at very low cost to most of the world within only a few days (Williams 2009).

The analysis of transport statistics shows that the Paris food supply areas at the beginning of the twenty-first century had obviously extended in space but had remained closer than expected to its traditional hinterland (Fig. 6a-c). For cereals, the contribution of the Paris basin remained as high as $70 \%$, in spite of significant long-distance imports, mainly from Italy. The weighted mean supply distance was $492 \mathrm{~km}$. For animal products, the French regions specialised in livestock farming: the areas west and north of Paris together contributed $50 \%$ of the supply; longer-distance supply, mostly from Europe, was significant. The mean supply distance was $660 \mathrm{~km}$, almost twice the distance of one century before. For fruit and vegetables also, more than $50 \%$ of the Paris supply in terms of $N$ content came from the Paris basin; the other half originated from much more dispersed and remote areas, extending to the African continent. The mean supply distance was $790 \mathrm{~km}$, in contrast to less than $100 \mathrm{~km}$ in 1896 .
In total, summing up all contributions to the Parisian diet (excluding fish), the mean weighted supply distance was about $660 \mathrm{~km}$ (Fig. 7). The departments within the Seine watershed (Paris's traditional food supply hinterland) still contributed $54 \%$ of the total proteins and $63 \%$ of plant proteins consumed by the city, while the adjoining territory formed by Brittany, Normandy and Nord-Pas-de-Calais contributed most of the animal protein supply. These two territories together provided $70 \%$ of the Paris food demand, while the remaining 30\% came equally from other French départements and foreign countries.

\section{Discussion}

Long-term evolution of Paris food supply areas

The major findings of this study are summarised in Table 2. They show that over the last two centuries, in spite of a considerable increase in the distances from which food is brought to the metropolis, the traditional food supply area of Paris, approximately a $150 \mathrm{~km}$ radius around the city, which roughly coincides with the Seine watershed, remained more significant in feeding the city than the changes in agriculture and transport infrastructures would have led one to expect. Of the total supply of cereals, $75 \%$ continues to come from the intensive agricultural areas of the central Paris basin, which, however, exports most of its huge production to foreign markets. In spite of a large diversity of origins throughout the world, most particularly Africa, approximately $50 \%$ of fruits and vegetables still come from areas located less than $150 \mathrm{~km}$ from Paris. However, as animal husbandry has been gradually banned from the central Paris basin, now mostly devoted to cereal production, the provision of animal products to Paris 
Fig. 6 Contribution of the French departments and foreign countries to the supply of Paris in cereals (a), animal products (b) and fruits/vegetables (c) in 2006. The distribution of supply distances is also indicated
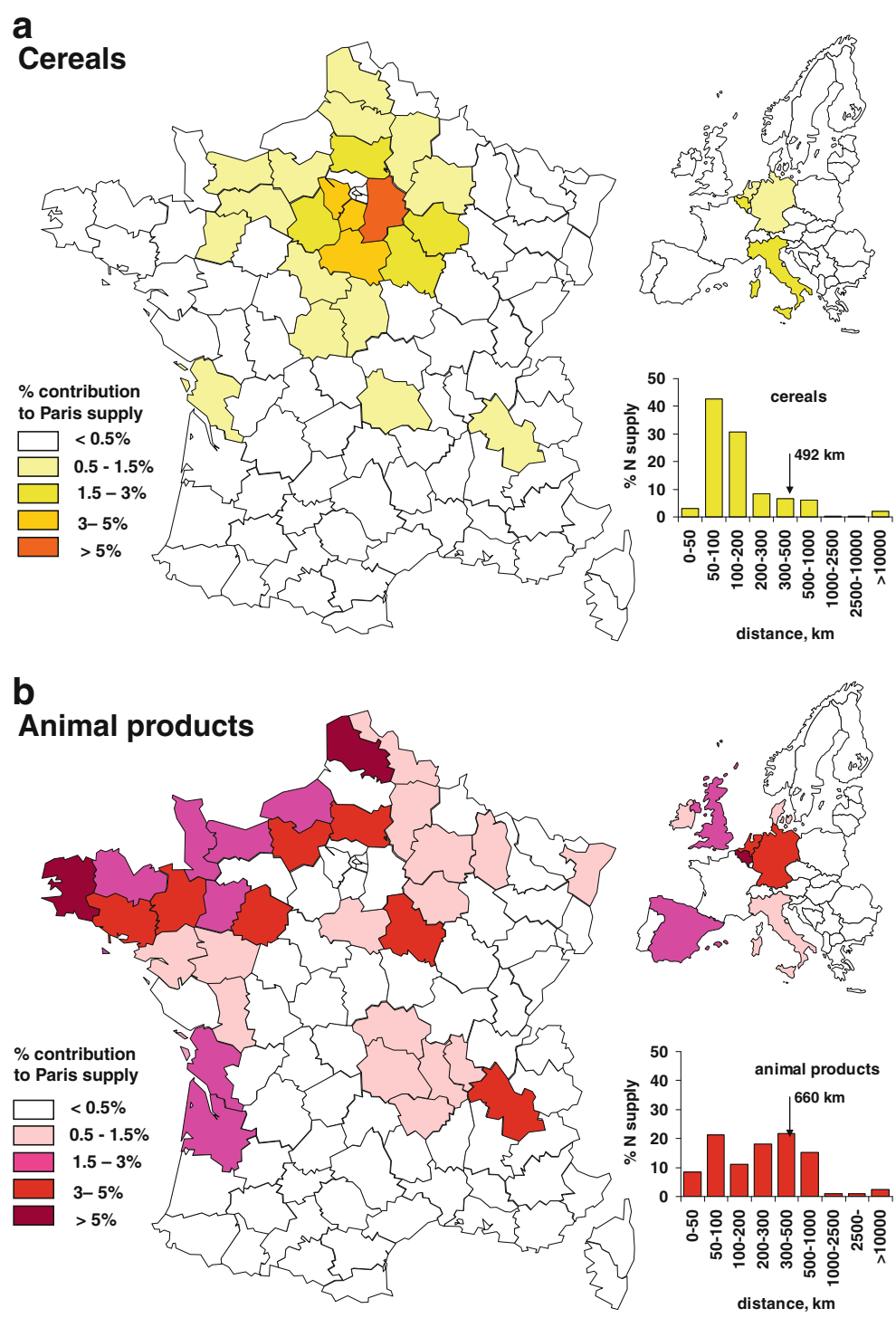

C

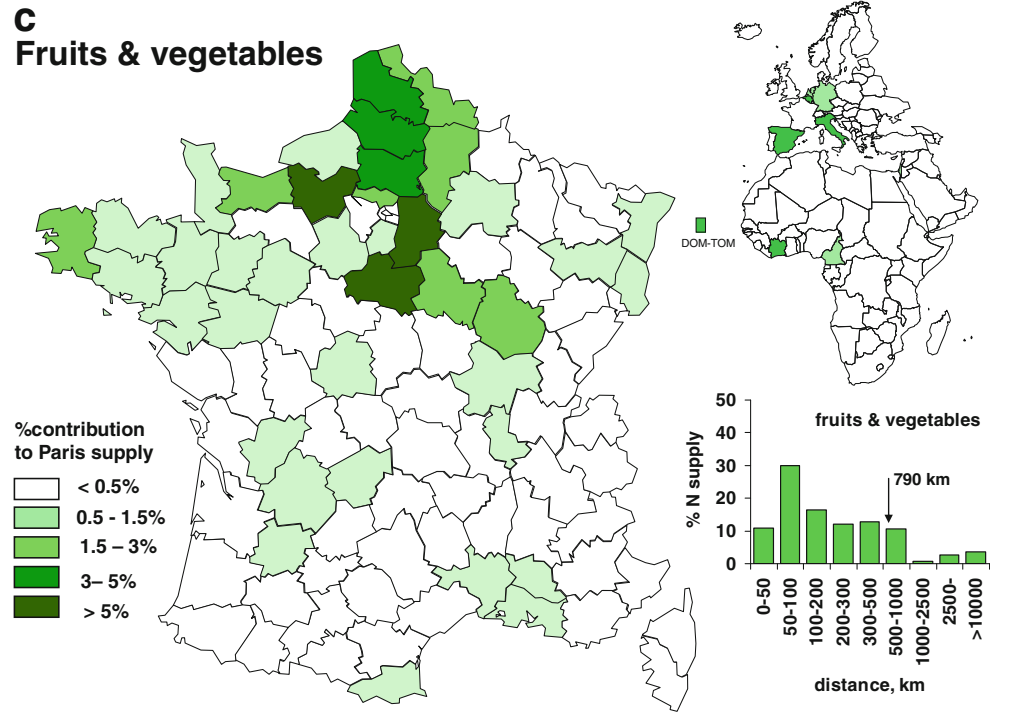




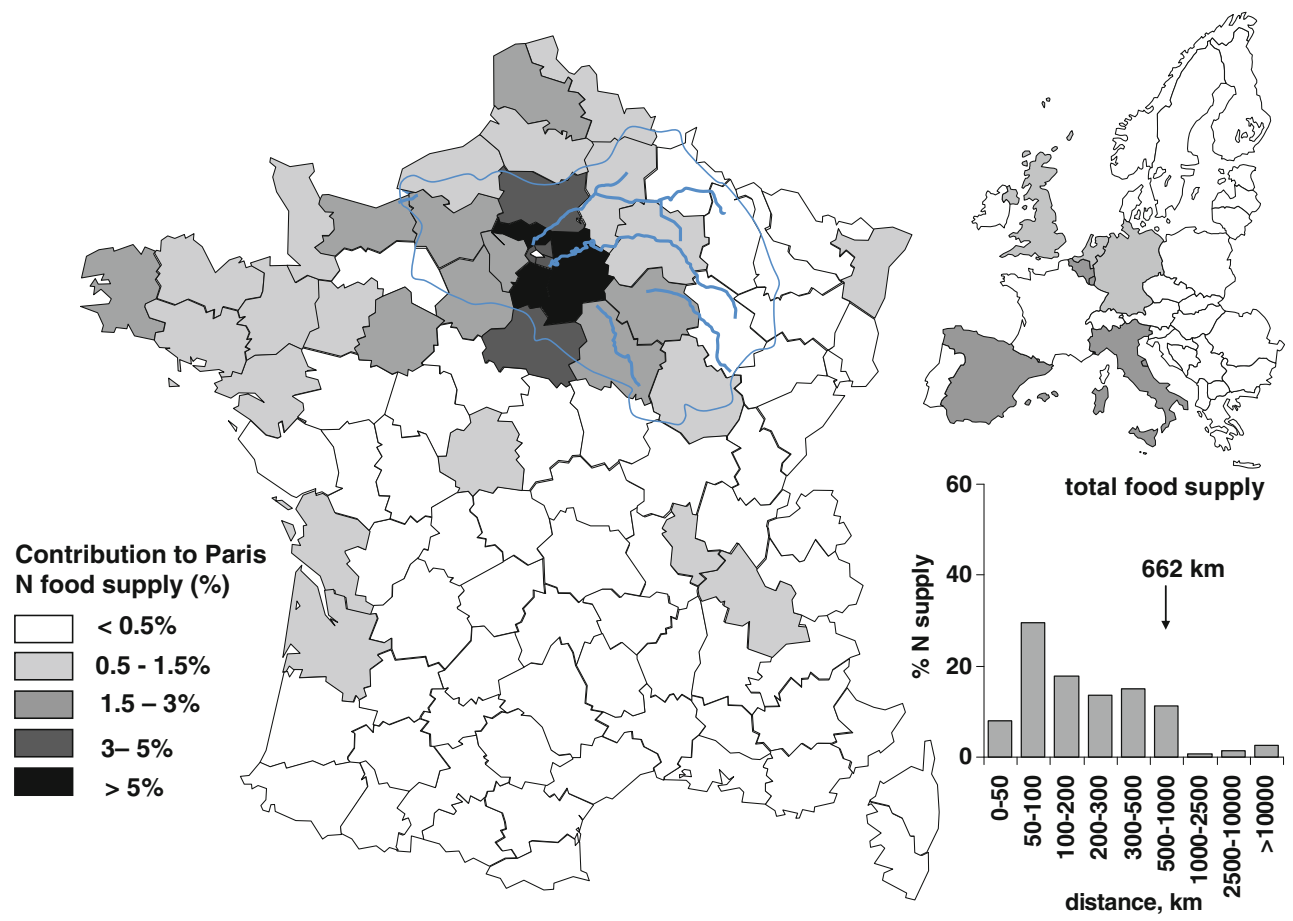

Fig. 7 Contribution of the French départements and foreign countries to the total protein supply of Paris in 2006. The distribution of weighted supply distances is also indicated

Table 2 Metropolitan Paris population, consumption of cereals, animal products and vegetables, and corresponding supply distances in 1786, 1896 and 2006

\begin{tabular}{|c|c|c|c|}
\hline & 1786 & 1896 & 2006 \\
\hline Metropolitan Paris population, inhabitants & 700,000 & $3,340,500$ & $11,532,000$ \\
\hline Total food consumption (including fish), ktonN/year & 3.74 & 23.5 & 93.0 \\
\hline Weighted mean import distance, $\mathrm{km}$ & 170 & 266 & 662 \\
\hline \multicolumn{4}{|l|}{ Cereals } \\
\hline Paris agglomeration consumption, ktonN/year & 2.1 & 8.8 & 15.6 \\
\hline Weighted mean import distance, $\mathrm{km}$ & 110 & 177 & 492 \\
\hline \multicolumn{4}{|l|}{ Animal products (excl. fish) } \\
\hline Paris agglomeration consumption, kTN/year & 1.2 & 12.2 & 55.6 \\
\hline Weighted mean import distance, $\mathrm{km}$ & 255 & 325 & 660 \\
\hline \multicolumn{4}{|l|}{ Fruits and vegetables } \\
\hline Paris agglomeration consumption, kTN/year & 0.15 & 1.34 & 13.0 \\
\hline Weighted mean import distance, $\mathrm{km}$ & 87 & 97 & 770 \\
\hline
\end{tabular}

mostly originates from the contiguous West and North regions of France, which have specialised in intensive livestock farming.

The biogeochemical functioning of the present main food supply area for Paris

The regional specialisation of agriculture in either crop or animal farming has resulted in the separation of Paris's main food supply into two territories with distinct agricultural orientations (Fig. 8). The first one, roughly corresponding to the Seine watershed, is characterised by the dominance of cereal crops, grown with intensive application of synthetic fertilisers; it provides most plant products consumed by the city and still exports more than $80 \%$ of its production. However, it supplies less than $20 \%$ of the population's requirements of animal products. By contrast, the second territory, corresponding to Brittany, Normandy and Nord-Pas-de-Calais, which supplies most of the meat and milk requirements of the Paris metropolitan area, is characterised by a very high livestock density, and its nitrogen cycle is dominated by the huge fluxes associated with livestock feeding and excretion. A large part of animal feed is made of imported soybean and soybean oilcake meals from Brazil and Argentina. The analysis of the SitraM database estimates these imports at 

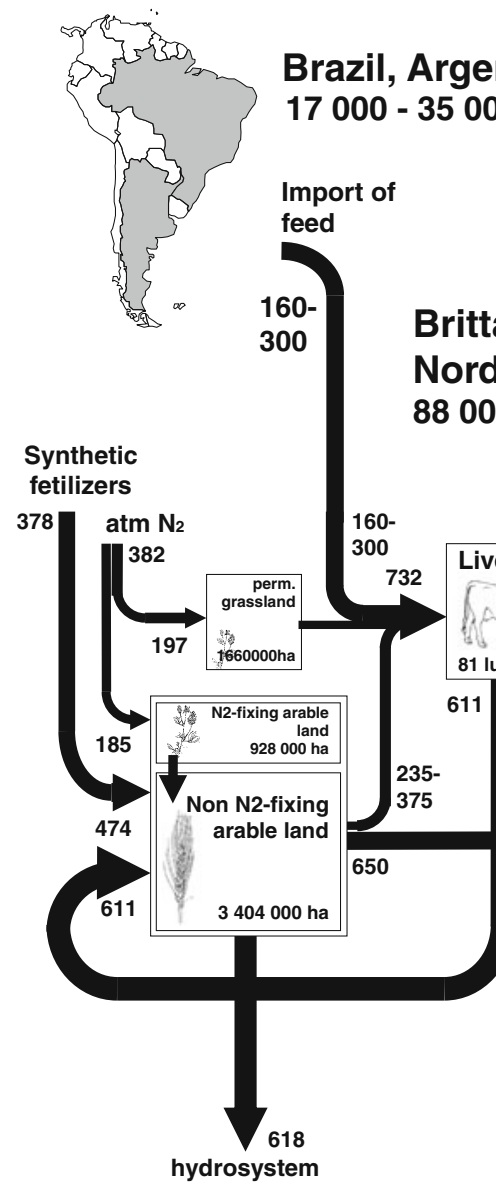

\section{Brittany, Normandy, Nord-Pas de Calais $88000 \mathrm{~km}^{2}$}

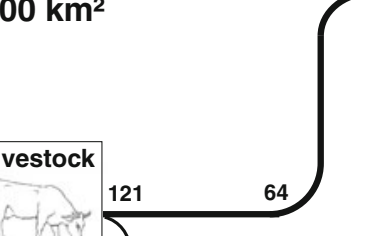

Fig. 8 The nitrogen cycle in Paris food supply areas

$300 \mathrm{ktonN} / \mathrm{year}$. The calculation based on the current livestock feed formula (Chatzimpiros and Barles 2010) yields a lower figure (160 ktonN/year), which remains quite high in terms of the ratio of imported to locally produced livestock protein, however. Taking into account the soybean yield in South America (about 2.5 ton/ha/year, i.e. $88 \mathrm{kgN} / \mathrm{ha} /$ year FAOstat 2006), and after allocating the land requirements to grow soybean between the meal and the oil derivatives (Chatzimpiros and Barles 2010), these imports correspond to an agricultural area of about $17,000-30,000 \mathrm{~km}^{2}$, a territory comparable in size to the one considered here.

Our paradoxical conclusion is therefore that the enlargement of Paris foodprint is less related to the extension of the direct supply areas than to the opening and specialisation of French agriculture. Except for a number of exotic products contributing only marginally to the total food intake, and as far as this remained possible in view of the specialisation of the agricultural system itself, Paris food consumption seems to have remained anchored to a large extent in its traditional hinterland, even though the corresponding rural territory has turned away from its privileged relationship with the city and resolutely entered a globalisation dynamic. French agriculture has opened to the world, while Paris remains supplied to an unexpected extent by its surrounding areas.

\section{Conclusion}

We currently lack precise data to compare our analysis of the Paris case study with that of other megalopolises in the world. The fact that Paris, like Vienna, Madrid and Moscow, is a continental city with, until recently, limited access to the sea, might have been a factor for the observation that the city's food supply is solidly anchored in the surrounding farmlands. By comparison, London, Barcelona, Amsterdam and all large US east coast cities might well more easily rely on distant overseas supply areas. It is also clear that the achievement of food security has long been a political priority for French authorities, whatever the successive political regimes. Examples of political actions taken to develop productive national agriculture in France are facilitation of wide access to land ownership by 
sale of new National Goods after the 1789 French Revolution, strict protectionist policies against cereal imports throughout the nineteenth century, and creation of a powerful Ministry of Agriculture in 1881 during the 3rd Republic (Hervieu 2008), which still exists today and remains separate from the Ministry in charge of environmental issues. All these factors might explain the perhaps exceptionally close food supply of Paris. Given the role played by food in shaping our lives and cities, as convincingly demonstrated by architect Carolyn Steel (2008) in her book Hungry City, this may be a considerable asset for Paris in terms of environmental sustainability.

As we have shown, the main causes of enlargement of the environmental imprint of Paris food consumption lie in the evolution of the agricultural sector itself, with (1) the regional specialisation to grain monoculture in the centre of the Paris basin and livestock farming in the northwest of France and (2) the massive shift of livestock farming to imported feed. The increased proportion of animal products in the human diet, which increased from 39 to $69 \%$ of the total protein intake, has been a strong incentive for this evolution.

Acknowledgments This study was conducted within the Interdisciplinary Research Programme on City and Environment (PIRVE) directed by the French Ministry of Ecology, Sustainable Development, Transport and Housing (MEDDATT) and the CNRS, the ANR 'Ville Durable' Programme CONFLUENT and the 'Paris 2030' programme funded by the Ville de Paris. It is part of the activities coordinated by the FIRE (Fédération Ile-de-France de Recherches sur l'Environnement) and the PIREN-Seine Programme.

Open Access This article is distributed under the terms of the Creative Commons Attribution Noncommercial License which permits any noncommercial use, distribution, and reproduction in any medium, provided the original author(s) and source are credited.

\section{References}

Abad R (2002) Le Grand Marché: l'approvisionnement de Paris sous l'Ancien Régime. Fayard, Paris

Agreste (2006) http://www.agreste.agriculture.gouv.fr/

Barles S (2007) Feeding the city: food consumption and flow of nitrogen, Paris, 1801-1914. Sci Total Environ 275:48-58
Billen G, Garnier J, Nemery J, Sebilo M, Sferratore A, Benoit P, Barles S, Benoit M (2007) A long term view of nutrient transfers through the Seine river continuum. Sci Total Environ 275:80-97

Billen G, Barles S, Garnier J, Rouillard J, Benoit P (2009) The foodprint of Paris: long term reconstruction of the nitrogen flows imported to the city from its rural Hinterland. Reg Environ Change 9:13-24

Bureau de l'approvisionnement (Préfecture du Département de la Seine) (1897) Rapport annuel de l'année 1896 sur les services municipaux de l'approvisionnement de Paris. Préfecture du département de la Seine, Paris

Chatzimpiros P, Barles S (2010) Nitrogen, land and water inputs in changing cattle farming systems. A historical comparison for France, 19th-21st centuries. Sci Total Environ 408:4644-4653

Dupeux G (1981) Atlas historique de l'urbanisation en France (1811-1975). éditions du CNRS, Paris

FAOstat (2006) http://faostat.fao.org/

Favier J (1997) Paris, deux mille ans d'histoire. Fayard, Paris

Fierro A (1996) Histoire et dictionnaire de Paris. Robert Laffont, Paris

Hervieu B (2008) Les orphelins de l'exode rural; Essai sur l'agriculture et les campagnes du XXIe siècle. Editions de l'Aube

INSEE (2007) http://www.insee.fr/fr/methodes/default.asp?page= definitions/unite-urbaine.htm

Jouanne A (1859) Atlas historique et statistique des chemins de fer français. Hachette, Paris

Kim E, Barles S (2011) The energy consumption of Paris and its supply areas from eighteenth century to present. Reg Environ Change (in press)

Mazoyer M, Roudart L (1998) Histoire des agricultures du monde. Du Néolithique à la crise contemporaine. Seuil, Paris

Ministère du Commerce et de l'Industrie (1897) Annuaire statistique de la France, 1895-1896. Imprimerie Nationale, Paris

Morley NDG (1996) Metropolis and Hinterland. The city of Rome and the Italian economy, 200 B.C.-A.D. 200. Cambridge University Press, Cambridge

Mouchel JM, Boët P, Hubert G, Guerrini M-C (1998) Un bassin et des hommes: une histoire tourmentée. In: Meybeck M, de Marsily G, Fustec E (eds) La Seine en son Bassin. Elsevier, Paris. pp 77-125

Peet JR (1969) The spatial expansion of commercial agriculture in the nineteenth century: a Von Thunen interpretation. Econ Geogr 45:283-301

Steel C (2008) Hungry city. How food shapes our lives. Chatto \& Windus, Vintage, London

Sutton M, Howard C, Erisman JW, Billen G, Bleeker A, Grennfelt P, van Grinsven H, Grizzetti B (eds) (2011) The European nitrogen assessment: sources, effects and policy perspectives. Cambridge University Press

Williams C (2009) Where's the remotest place on Earth? New Sci 2704:40-43 